\title{
Early Amiodarone Use in A Patient With COVID-19 Pneumonia
}

\author{
Khaled Jamoor ${ }^{1}$, Mohamad Raad ${ }^{2}$, Najia Huda ${ }^{3}$ and Waddah Maskoun ${ }^{4 *}$ \\ ${ }^{1}$ Department of Internal Medicine, Henry Ford Macomb Hospital, Macomb, Michigan, USA \\ ${ }^{2}$ Division of Cardiology, Department of Medicine, Henry Ford Hospital, Detroit, Michigan, USA \\ ${ }^{3}$ Division of Pulmonary and Critical Care Medicine, Department of Medicine, Henry Ford Hospital, USA \\ ${ }^{4}$ Division of Electrophysiology, Henry Ford Heart \& Vascular institute, Henry Ford Hospital and Health System, USA
}

*Corresponding author: Waddah Maskoun, Division of Electrophysiology, Henry Ford Heart \& Vascular institute, Henry Ford Hospital and Health System, USA.

To Cite This Article: Khaled J, Mohamad R, Najia H, Waddah M, Early Amiodarone Use in A Patient With COVID-19 Pneumonia. 2020 - 10(1). AJBSR. MS.ID.001468. DOI: 10.34297/AJBSR.2020.10.001468.

Received: 阱 July 27, 2020; Published: 筒 August 24, 2020

\begin{abstract}
Coronavirus disease 19 (COVID-19) has caused a global pandemic since its emergence in late 2019. Most cases cause a mild self-limiting disease, but it can also lead to a variety of organ failure and most notably respiratory failure. To date there is no clinically proven treatment for COVID-19 infection. Amiodarone was shown to have in-vitro activity against Filovirus species with potential antiviral activity against SARS-CoV-2. The current case describes the clinical response after starting amiodarone in critically ill COVID-19 patient with multi organ failure. Here we present a case of a 66-years old male who developed acute respiratory distress syndrome (ARDS) secondary to COVID-19 infection requiring mechanical ventilation, renal failure requiring renal replacement therapy, and significant encephalopathy He was started on amiodarone to control his atrial fibrillation and we noticed significant drop in his oxygen requirements afterwards resulting in early liberation from the ventilator. Our patient had a measurable clinical improvement after starting amiodarone and he was liberated from the ventilator within less than 48 hours which is atypical for COVID-19 induced ARDS. We here present our observation in an attempt to explore the potential role of amiodarone in management of COVID-19 infection especially if introduced early in the course of the disease.
\end{abstract}

Keywords: COVID-19; Severe acute respiratory syndrome virus; Amiodarone; Cationic amphiphilic drugs

Abbreviations: COVID-19: Corona Virus Disease 19; ARDS: Acute Respiratory Distress Syndrome; AF: Atrial Fibrillation; RVR: Rapid Ventricular Response; Pa02: Partial Pressure of Arterial Oxygen; $\mathrm{FIO}_{2}$ : Fraction of Inspired Oxygen; ACE2: Angiotensin Converting Enzyme 2; PCR: Polymerase Chain Reaction; IV: Intravenous; DKA: Diabetic Ketoacidosis; SARS-CoV2: Severe Acute Respiratory Syndrome Coronavirus 2.

\section{Introduction}

Novel coronavirus disease-19 (COVID-19) is a global pandemic disease with multiorgan involvement [1]. COVID-19 virus enters the host cell via interaction with the Angiotensin converting enzyme 2 (ACE-2) receptor. Afterwards it is transmitted to the endosome where it undergoes important steps for viral replication [2]. Amiodarone can accumulate in the endosome, disrupting its environment and interfering with the viral replication process [3].

\section{Case Presentation}

The patient is a 66-years old male with a history of hypertension, diabetes mellitus type 2 , obesity with body mass index of 40 , chronic kidney disease stage-III, and paroxysmal atrial fibrillation who presented with 1 week of fever, chills, altered mental status and shortness of breath with a productive cough. Upon presentation his blood pressure was $102 / 55 \mathrm{mmHg}$, heart rate 121 beats per minute, respiratory rate 25 breaths per minute, temperature $38.3^{\circ} \mathrm{C}$, and his oxygen saturation was $86 \%$ on room air. He had diffuse crackles on pulmonary auscultation, an irregular rhythm and a Glasgow Coma Scale of 7 without any focal neurologic deficits. Chest x-ray and CT scan revealed a right small pneumomediastinum in addition to bilateral infiltrates with diffuse ground glass opacities (Figure 1). His electrocardiogram showed atrial fibrillation (AF) with rapid 
ventricular response (RVR). His labs showed acute kidney injury, elevated inflammatory markers and troponin, lymphopenia, in addition to findings consistent with diabetic ketoacidosis (DKA)
(Table 1). His polymerase chain reaction (PCR) for Severe Acute Respiratory Syndrome Coronavirus 2 (SARS-CoV2) was positive.

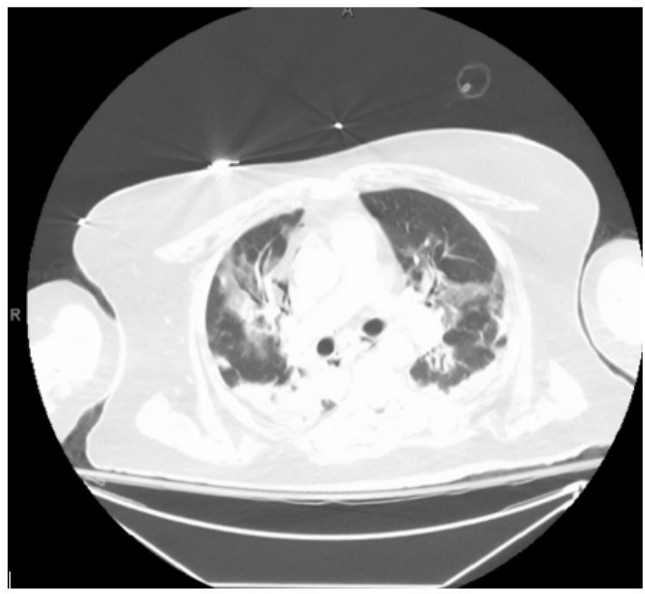

Figure 1: CT scan of the chest showing bilateral infiltrates, bilateral ground glass opacities and pneumomediastinum.

\section{Treatment and Outcome}

Our patient was intubated in the emergency department and required norepinephrine for hypotension. Intravenous (IV) and oral Amiodarone were started 9 hours after intubation to control his atrial fibrillation. He required high oxygen support with a Pa02: $\mathrm{FiO2} \%$ ratio of 158 initially which was consistent with moderate acute respiratory distress syndrome (ARDS). However, we were able to downgrade his oxygen requirements within 4 hours of starting Amiodarone (Table 2). He was extubated to $3 \mathrm{~L}$ nasal canula within 45 hours of intubation. His DKA resolved with IV insulin, fluids, and his pneumomediastinum was monitored with no surgical intervention. He also received IV Vancomycin,

Table 1: Laboratory values on admission.

\begin{tabular}{|c|c|c|}
\hline Lab & Admission Lab & $135-145 \mathrm{mmol} / \mathrm{L}$ \\
\hline Sodium & $132 \mathrm{mmol} / \mathrm{L}$ & $3.5-5 \mathrm{mmol} / \mathrm{L}$ \\
\hline Potassium & $5.5 \mathrm{mmol} / \mathrm{L}$ & $98-111 \mathrm{mmol} / \mathrm{L}$ \\
\hline Chloride & $93 \mathrm{mmol} / \mathrm{L}$ & $21-35 \mathrm{mmol} / \mathrm{L}$ \\
\hline Bicarbonate & $15 \mathrm{mmol} / \mathrm{L}$ & $3-13$ \\
\hline Anion Gap & 24 & $10-25 \mathrm{mg} / \mathrm{dL}$ \\
\hline BUN & $116 \mathrm{mg} / \mathrm{dL}$ & $<1.13 \mathrm{mg} / \mathrm{dL}$ \\
\hline Creatinine & $3.98 \mathrm{mg} / \mathrm{dL}$ & $1.8-2.3 \mathrm{mg} / \mathrm{dL}$ \\
\hline Magnesium & $2.8 \mathrm{mg} / \mathrm{dL}$ & $3.8-10.6 \mathrm{k} / \mathrm{uL}$ \\
\hline WBC & $8.8 \mathrm{k} / \mathrm{uL}$ & $1.8-7.7 \mathrm{k} / \mathrm{uL}$ \\
\hline Neutrophils & $7.7 \mathrm{k} / \mathrm{uL}$ & $1.1-4 \mathrm{k} / \mathrm{uL}$ \\
\hline Lymphocytes & $0.4 \mathrm{k} / \mathrm{uL}$ & $13.5-17 \mathrm{~g} / \mathrm{dL}$ \\
\hline Hemoglobin & $13.6 \mathrm{~g} / \mathrm{dL}$ & $<50 \mathrm{pg} / \mathrm{mL}$ \\
\hline BNP & $405 \mathrm{pg} / \mathrm{mL}$ & $<18 \mathrm{ng} / \mathrm{L}$ \\
\hline
\end{tabular}

Piperacillin-Tazobactam, Interleukin 6 inhibitor (Tocilizumab 400 mg IV x 1 after 18 hours of intubation), methylprednisolone and he was started on IV unfractionated heparin for atrial fibrillation and elevated CHA2DS2-VASc score. He was also started on hemodialysis due to oliguric acute kidney injury. The patient was transferred out of the ICU on day 7 requiring 3 Liters of oxygen on the nasal canula. His post ICU course was complicated by Methicillin sensitive Staphylococcus aureus for which he completed a course of Cefazolin and unexplained altered mental status [4]. He required a total of 4 sessions of hemodialysis. The patient was later discharged to a rehabilitation facility with normal mental status, off any supplemental oxygen and off hemodialysis with creatinine close to baseline $(1.74 \mathrm{mg} / \mathrm{dL})$. 


\begin{tabular}{|c|c|c|}
\hline ALT & $46 \mathrm{IU} / \mathrm{L}$ & $<52 \mathrm{IU} / \mathrm{L}$ \\
\hline AST & $31 \mathrm{IU} / \mathrm{L}$ & $<35 \mathrm{IU} / \mathrm{L}$ \\
\hline Albumin & $3.2 \mathrm{~g} / \mathrm{dL}$ & $<2.1 \mathrm{mmol} / \mathrm{L}$ \\
\hline Lactic Acid & $1.1 \mathrm{mmol} / \mathrm{L}$ & $<0.66 \mathrm{ug} / \mathrm{mL}$ \\
\hline D-dimer & $2.71 \mathrm{ug} / \mathrm{mL}$ & $100-220 \mathrm{IU} / \mathrm{L}$ \\
\hline LDH & $381 \mathrm{IU} / \mathrm{L}$ & $<0.5 \mathrm{mg} / \mathrm{dL}$ \\
\hline C-reactive Protein & $15.7 \mathrm{mg} / \mathrm{dL}$ & $24-336 \mathrm{ng} / \mathrm{mL}$ \\
\hline Ferritin & $1458 \mathrm{ng} / \mathrm{mL}$ & $<0.25 \mathrm{ng} / \mathrm{mL}$ \\
\hline Procalcitonin & $0.93 \mathrm{ng} / \mathrm{mL}$ & $0-0.3 \mathrm{mmol} / \mathrm{L}$ \\
\hline BHB & $6.42 \mathrm{mmol} / \mathrm{L}$ & \\
\hline
\end{tabular}

Abbreviations: BUN: Blood Urea Nitrogen; BNP: Brain Natriuretic Peptide; ALT: Alanine Aminotransferase; AST: Aspartate Aminotransferase; WBC: White Blood Cells Count; LDH: Lactate Dehydrogenase; BHB: Beta Hydroxybutyrate

Table 2: Ventilator settings with corresponding arterial blood gas analysis and vital signs.

\begin{tabular}{|c|c|c|c|}
\hline & Intubation $+\mathbf{3 0}$ minutes $(+30$ minutes) & Amiodarone Start ( +9 hours) & Amiodarone Start +4 hours ( +13 hours) \\
\hline \multicolumn{4}{|c|}{ Vital signs } \\
\hline Heart rate (rhythm) & 125 beats/minute $(\mathrm{AF})$ & 172 beats/minute $(\mathrm{AF})$ & 118 beats/minute (AF) \\
\hline Blood pressure & $96 / 54 \mathrm{mmHg}$ & $98 / 56 \mathrm{mmHg}$ & $113 / 64 \mathrm{mmHg}$ \\
\hline Norepinephrine dose & $6 \mathrm{mcg} / \mathrm{min}$ & $22 \mathrm{mcg} / \mathrm{min}$ & $6 \mathrm{mcg} / \mathrm{min}$ \\
\hline \multicolumn{4}{|c|}{ ABG } \\
\hline $\mathrm{PH}$ & 7.15 & 7.34 & 7.37 \\
\hline $\mathrm{PaO}_{2}$ & $158 \mathrm{mmHg}$ & $64.5 \mathrm{mmHg}$ & $95.4 \mathrm{mmHg}$ \\
\hline $\mathrm{PCO}_{2}$ & $50.8 \mathrm{mmHg}$ & $46.4 \mathrm{mmHg}$ & $40.3 \mathrm{mmHg}$ \\
\hline $\mathrm{SaO}_{2} \%$ & $99 \%$ & $95 \%$ & $97.20 \%$ \\
\hline \multicolumn{4}{|c|}{ Ventilator setting } \\
\hline VT/RR & $400 \mathrm{ml} / 25$ & $480 \mathrm{ml} / 25$ & $480 \mathrm{ml} / 25$ \\
\hline $\mathrm{FIO}_{2} \% / \mathrm{PEEP}$ & $100 \% / 5 \mathrm{~cm} \mathrm{H}_{2} \mathrm{O}$ & $80 \% / 10 \mathrm{~cm} \mathrm{H}_{2} \mathrm{O}$ & $60 \% / 10 \mathrm{~cm} \mathrm{H}_{2} \mathrm{O}$ \\
\hline $\mathrm{PaO}_{2} / \mathrm{FIO}_{2} \%$ ratio & 158 & 80.62 & 159 \\
\hline
\end{tabular}

Abbreviations: AF: Atrial Fibrillation; ABG: Arterial Blood Gas; $\mathrm{PaO}_{2}$ : Arterial Partial Pressure of Oxygen; $\mathrm{PCO}_{2}$ : Partial Pressure of Carbon Dioxide; $\mathrm{SaO}_{2} \%$ : Oxygen Saturation Percentage; VT: Tidal Volume; RR: Respiratory Rate; $\mathrm{FIO}_{2} \%$ : Fraction of Inspired Oxygen; PEEP: Positive End Expiratory Pressure

\section{Discussion}

Amiodarone was reported to have antiviral activity in vitro against Filovirus species [3,5]. It had also been tested during the Ebola virus crisis with inconclusive data [6,7], and its antiviral activity may potentially be extrapolated to SARS-CoV-2. Although our patient received multiple medications that can confound his rapid clinical improvement, he did have a measurable improvement after starting amiodarone early in the course of the disease leading to an early extubation. His kidney function and mental status were also back to normal by the time of discharge. In light of this clinical response and the previous reports about the antiviral activity of amiodarone, we feel that these observations are important to report. There has not been any proven effective treatment for COVID-19 virus to date and we feel that future animal and observational studies can shed some light on the potential role of amiodarone in COVID-19 infection, especially if introduced early in the course of the disease.

\section{Acknowledgements}

We would like to express our gratitude to all the health care workers fighting on the front lines during this global crisis.

\section{Conflict of Interest}

The authors declare that there is no conflict of interest.

\section{References}

1. Zaim S, Chong JH, Sankaranarayanan V, Harky A (2020) COVID-19 and Multiorgan Response. Curr Probl Cardiol 45(8): 100618.

2. Aimo A, Baritussio A, Emdin M, Tascini C (2020) Amiodarone as a possible therapy for coronavirus infection. Eur J Prev Cardiol 2047487320919233.

3. Salata C, Calistri A, Parolin C, Baritussio A, Palù G (2017) Antiviral activity of cationic amphiphilic drugs. Expert Rev Anti Infect Ther 15(5): 483-492.

4. Helms J, Kremer S, Merdji H, Clere Jehl R, Schenck M, et al. (2020) Neurologic Features in Severe SARS-CoV-2 Infection. N Engl J Med 382(23): 2268-2270 
5. Stadler K, Ha HR, Ciminale V, Spirli C, Saletti G, et al. (2008) Amiodarone alters late endosomes and inhibits SARS coronavirus infection at a postendosomal level. Am J Respir Cell Mol Biol 39(2): 142-149.

6. Wolf T, Kann G, Becker S, Stephan C, Brodt HR, et al. (2015) Severe Ebola virus disease with vascular leakage and multiorgan failure: treatment of a patient in intensive care. Lancet 385(9976): 1428-1435.
7. Lanini S, Portella G, Vairo F, Kobinger GP, Pesenti A, et al. (2015) Blood kinetics of Ebola virus in survivors and nonsurvivors. J Clin Invest 125(12): 4692- 4698. 